\title{
EXPERIMENTALWORKS
}

UDC 577.112.5/.6:576.311.347:616.61

doi: https://doi.org/10.15407/ubj91.03.019

\section{GLUTATHIONE INFLUENCE ON ENERGY \\ METABOLISM IN RAT LIVER MITOCHONDRIA \\ UNDER EXPERIMENTAL NEPHROPATHY}

\author{
Ye. O. FERENCHUK, I. V. GERUSH
}

\author{
Higher State Educational Establishment of Ukraine "Bukovinian State \\ Medical University”, Chernivtsi; \\ e-mail: yelena_f@ukr.net
}

Received: 17 October 2018; Accepted: 14 March 2019

\begin{abstract}
Mitochondrial oxidative damage and disorders of energy metabolism contribute to a wide range of pathologies and disease progression. In our work, the effect of glutathione on the activity of respiratory chain enzymes and the content of free SH-groups in rat liver mitochondria was examined with the use of folic acid-induced nephropathy model. Mitochondria were isolated by differential centrifugation, NADHdehydrogenase, succinate dehydrogenase, cytochrome oxidase and $H^{+}$-ATPase activity were determined. The activity of these enzymes and the content of the free SH-groups in the liver were shown to be decreased under conditions of nephropathy, evidently due to the intensification of the free radical processes. The introduction of glutathione increased the content of SH-groups and the activity of the Complexes II and V enzymes of mitochondrial respiratory chain but did not change the activity of cytochrome oxidase in mitochondria isolated from the liver of rats under experimental nephropathy. The results obtained demonstrate a positive effect of glutathione on mitochondrial succinate dehydrogenase and $H^{+}$-ATPase activity normalization in the liver of rats with nephropathy. These findings may help to extend the understanding of mitochondrial energy metabolism under development of kidney diseases.
\end{abstract}

Ke y wo rds: nephropathy, mitochondria, glutathione, NADH-dehydrogenase, succinate dehydrogenase, cytochrome oxidase, $H^{+}$-ATPase.

K idney disease often leads to the general state of oxidative stress and can co-exist with different liver diseases, or stimulate their development. The liver is the chemical center of the human body, consuming $20 \%$ of oxygen in the entire body and is important in the metabolism of sugar, fat, protein, water, salt and vitamins [1, 2].

It is known that hepatocytes are enriched with mitochondria that comprise $13-20 \%$ of the liver volume. And mitochondria play an important role in regulating energy metabolism: provides the oxidative phosphorylation and $\beta$-oxidation of fatty acids, participates in the maintaining of the cell calcium homeostasis, biosynthesis of lipids, heme, ironsulfur clusters and some amino acids etc. However, mitochondria are considered as the main source of reactive oxygen species which can influence intracellular signaling, regulation of cell functions and non-specific immune response [3, 4]. Also due to mitochondria high oxidation potential, the reactive oxygen species (ROS) are capable of damaging cell structure and inducing a number of chain reactions leading to the uncoupling of integration functions in the organism [5]. ROS production by mitochondria can lead to oxidative damage to mitochondrial proteins, membranes and DNA, impairing the abili-

(C) 2019 Ferenchuk Ye. O., Gerush I. V. This is an open-access article distributed under the terms of the Creative Commons Attribution License, which permits unrestricted use, distribution, and reproduction in any medium, provided the original author and source are credited. 
ty of mitochondria to synthesize ATP and carry out their wide range of metabolic functions, including the tricarboxylic acid cycle, fatty acid oxidation, the urea cycle, amino acid metabolism, haem synthesis and FeS centre assembly that are central to the normal operation of most cells. Mitochondrial oxidative damage can also increase the ability of mitochondria to release intermembrane space proteins such as cytochrome c to the cytosol by mitochondrial outer membrane permeabilization and thereby activate the cell's apoptotic machinery [6-8].

And it is unsurprising that mitochondrial oxidative damage and disorders of energy metabolism contribute to a wide range of pathologies and disease progression. The link between the development of nephropathy, formation ROS and state of energy metabolism in the liver are incompletely understood. Therefore, investigating the association between kidney disease and energy metabolism in the liver and influence of glutathione as one of antioxidants has important practical value for understanding the mechanisms underlying nephropathy, providing a basis for the understanding of energy metabolism under physiological and pathophysiological conditions will help improve complex therapeutic strategies for patients with kidney and liver diseases.

So the aim of our study was to examine the effect of glutathione on the activity of enzymes of the mitochondrial respiratory chain and determine the content of SH-groups in the mitochondria of the liver of rats with folic acid-induced nephropathy model.

\section{Materials and Methods}

The experiment was conducted on 131 male albino rats with the body weight $0.16-0.18 \mathrm{~kg}$. Experimental nephropathy was modeled by injection of a single intraperitoneal dose of folic acid (250 mg/ $\mathrm{kg}$, Sigma-Aldrich) [9]. To confirm the pathology, the kidneys were examined by morphometric analysis. Thus we determined that the rapid appearance of folic acid crystals inside the renal tubules caused alteration of the epithelium of the proximal tubule of the kidney, inflammatory cell infiltration and caused necrosis and the cortical scarring. Damage of the epithelium of the proximal tubules with the subsequent proliferation of tubulointerstitial disintegration on the renal cortex, renal medulla, and renal papillae led to a decrease of filtering capacity of the kidneys.

Glutathione (Sigma-Aldrich) was introduced daily (100 mg/kg) by the intragastric way for 3 and 7 days following after the injection of folic acid. Ani- mals were narcotized with chloroform and sacrificed on the next day after the last glutathione introduction. All manipulations with animals were carried out according to the European Convention for the Protection of Vertebrate Animals used for Experimental and Other Scientific Purposes and law of Ukraine "On protection of animals from cruelty". Rats were kept under the standard vivarium conditions at a constant temperature and basic allowance. All procedures were executed separately from other rats.

Mitochondria were isolated by differential centrifugation in the isolation buffer [10]. The rats liver was washed with a cooled $0.9 \%$ solution of $\mathrm{KCl}$ $\left(2-4{ }^{\circ} \mathrm{C}\right)$, chopped and homogenized in 10 times the volume of buffer $\mathrm{pH}$ 7.4: sucrose $-250 \mathrm{mmol} / \mathrm{l}$, tris$\mathrm{HCl}-25 \mathrm{mmol} / \mathrm{l}$. The homogenate was centrifuged at $700 \mathrm{~g}$ for $10 \mathrm{~min}\left(4^{\circ} \mathrm{C}\right)$, and the supernatant at $11000 \mathrm{~g}$ for $20 \mathrm{~min}\left(4^{\circ} \mathrm{C}\right)$ using the centrifuge HERMLE Labortechnik. The precipitate was resuspended in $5 \mathrm{ml}$ of the same buffer (without EDTA) and centrifuged again under the same conditions. The resulting precipitate (mitochondrial fraction) was resuspended in buffer ( $\mathrm{mmol} / \mathrm{l})$ : sucrose -250 , Tris- $\mathrm{HCl}-25$ and used immediately in experiments. The activities of NADH-dehydrogenase, succinate dehydrogenase, cytochrome oxidase and $\mathrm{H}^{+}$-ATPase were determined in the mitochondria of the liver using the spectrophotometer Agilent Cary 60 .

NADH dehydrogenase activity was determined by the rate of NADH oxidation. $0.02 \mathrm{ml}$ of mitochondrial fractions and $100 \mu \mathrm{M}$ NADH were added to the test tubes containing $2 \mathrm{ml}$ of $0.02 \mathrm{M}$ trisphosphate buffer ( $\mathrm{pH}$ 7.4). Measurements were carried out at $340 \mathrm{~nm}$ per decrease in optical density for $2 \mathrm{~min}$ with an interval of $20 \mathrm{sec}$ [11]. The activity of NADdehydrogenase was calculated on the basis of molar extinction $6.22 \cdot 10^{3} \mathrm{M}^{-1} \mathrm{~cm}^{-1}$.

The succinate dehydrogenase activity was measured based on restoration of potassium ferricyanide $\left(\mathrm{K}_{3}\left[\mathrm{Fe}(\mathrm{CN})_{6}\right]\right)$ to colorless potassium ferrocyanide $\left(\mathrm{K}_{4}\left[\mathrm{Fe}(\mathrm{CN})_{6}\right]\right)$ by the action of succinate dehydrogenase [12]. The suspension of mitochondria $(0.2 \mathrm{ml})$ was added to incubation solution $(10 \mathrm{mM}$ phosphate buffer ( $\mathrm{pH} 7.8), 5 \mathrm{mM}$ succinic acid, 1.25 mM EDTA, 7.5 mM sodium azide) Samples were incubated at room temperature for $5 \mathrm{~min}$. The reaction was initiated by the addition of $1.25 \mathrm{mM}$ potassium ferricyanide solution to the samples. Samples were incubated for $10 \mathrm{~min}$ at $30^{\circ} \mathrm{C}$. After incubation, the reaction was stopped by lowering the sample temperature to $0^{\circ} \mathrm{C}$. In the control samples 
containing all components of the incubation mixture, $\mathrm{CCl}_{3} \mathrm{COOH}$ was added before the introduction of the mitochondrial suspension. After stopping the reaction, the samples were analyzed at $\lambda 420 \mathrm{~nm}$. The activity of the enzyme is proportional to the amount of ferricyanide.

Method of determination cytochrome oxidase is based on the ability of the enzyme to oxidize dimethylparaphenylidine and $\alpha$-naphthol with the formation of indophenol blue. Its concentration is proportional to cytochrome oxidase activity [13]. In the test tubes were injected $1 \mathrm{ml}$ of the reaction substrate $(\alpha$-naphthol, paraphenyldiamine and sodium carbonate in a ratio of 1:1:1). To these mixtures were added to $0.1 \mathrm{ml}$ of the mitochondrial fraction suspension (and $0.1 \mathrm{ml}$ of $\mathrm{H}_{2} \mathrm{O}$ in the control test tube). After incubation (30 min) $3 \mathrm{ml}$ of ethanol was added to each test tube. Samples were centrifuged for $10 \mathrm{~min}$ at $6000 \mathrm{~g}$. The samples were measured by spectrophotometrically at $\lambda 550 \mathrm{~nm}$.

$\mathrm{H}^{+}$-ATPase activity was evaluated according to the accumulation of inorganic phosphate [14]. The activity was determined in an incubation solution containing $400 \mu \mathrm{mol}$ of tris- $\mathrm{HCl}(\mathrm{pH} 7.4), 5 \mu \mathrm{mol}$ of ATP disodium salt, $7.5 \mu \mathrm{mol}$ of $\mathrm{MgSO}_{4} \cdot 10^{-2} \mu \mathrm{mol}$ of 2,4-dinitrophenol, $7.5 \mu \mathrm{mol}$ of $\mathrm{CaCl}_{2}, 120 \mu \mathrm{mol}$ of $\mathrm{NaCl}, 20 \mu \mathrm{mol}$ of $\mathrm{KCl}$. The reaction was initiated by the addition of $50 \mu \mathrm{l}$ of a mitochondria suspension containing $1 \mathrm{mg}$ of protein, 267 incubated for $15 \mathrm{~min}$ at $37^{\circ} \mathrm{C}$. The reaction was stopped by the addition of $1 \mathrm{ml}$ of $10 \% \mathrm{CCl}_{3} \mathrm{COOH}$. The contents of $\mathrm{P}_{\mathrm{i}}$ were determined colorimetrically.

The protein level was determined by Lowry's method [15]. The content of SH-groups was determined by the method [16] based on the interaction of Elmann reagent (5,5'-dithio-bis(2-nitrobenzoic acid) with SH-groups. For determination of the total$\mathrm{SH}$ group level, the reaction mixture composed of $0.2 \mathrm{ml}$ of the examined suppression of mitochondria, $0.1 \mathrm{ml}$ of $\mathrm{NaOH}, 3.7 \mathrm{ml}$ of phosphate buffer ( $\mathrm{pH} 8.0$ ),
$0.1 \mathrm{ml}$ of DTNB, was incubated for $10 \mathrm{~min}$ at room temperature and then the sample was centrifuged at $10000 \mathrm{~g}$ for $10 \mathrm{~min}$. The content of SH-groups was calculated using a molar extinction coefficient of $11400 \mathrm{M}^{-1} \mathrm{~cm}^{-1}$ and expressed in $\mathrm{nmol} / \mathrm{mg}$ protein.

The type of distribution was estimated using the Shapiro-Wilk test. Significant differences between group were evaluated by using the Wilcoxon test with $P<0.05$ considered [17]. All results in figures are represented as median minimum-maximum values (Me[min-max]).

\section{Results and Discussion}

The results of our experiment showed a decrease of NADH-dehydrogenase activity by $10 \%$ (Table) and succinate dehydrogenase activity by $26.8 \%$ (Fig. 1) in the mitochondria of hepatocytes of rats with nephropathy on the third day compared to the control group. Probably, the cause of this fact may be a violation of structural-functional organization of the I and II respiratory complexes chain under experimental conditions. At the same time, activities of cytochrome oxidase (Fig. 2) in the hepatocytes mitochondria of rats with nephropathy were decreased by $50 \%$ compared to animals of the control group. There was a decrease of NADH-dehydrogenase activity by $7 \%$ (Table) and succinate dehydrogenase activity by $16.7 \%$ (Fig. 1) in the mitochondria of hepatocytes of rats with nephropathy on the 7th day of the experiment compared to values of the control group. Such change can be considered as a compensatory reaction of the organism to oxidative stress caused by nephropathy.

Activities of cytochrome oxidase (Fig. 2) in the hepatocytes mitochondria of rats with nephropathy were decreased by 50\% during all experimental days compared to animals of the control group. The activity of $\mathrm{H}^{+}$-ATPase (Fig. 3) in the hepatocytes mitochondria of rats with nephropathy was decreased by $37.5 \%$ on the $3^{\text {rd }}$ experimental day and by $33 \%$ on

Activity of NADH-dehydrogenase in the mitochondria of the liver

\begin{tabular}{l|c|c|c|c|c}
\hline $\begin{array}{c}\text { Activity } \\
\text { of NADH-dehydrogenase }\end{array}$ & I, $n=36$ & II, $n=25$ & III, $n=23$ & IV, $n=24$ & V, $n=23$ \\
\hline $\begin{array}{l}\text { nmol NADH/min·mg } \\
\text { of protein }\end{array}$ & $20.98 \pm 0.28$ & $19.07 \pm 0.51^{*}$ & $20.57 \pm 0.31^{\#}$ & $19.52 \pm 0.38^{*}$ & $20.20 \pm 0.43$ \\
\hline
\end{tabular}

I - control, II - nephropathy ( $3^{\text {rd }}$ day), III - nephropathy +3 days of glutathione introduction, IV - nephropathy ( $7^{\text {th }}$ day), $\mathrm{V}-$ nephropathy +7 days of glutathione introduction; ${ }^{*} P<0.01$, relative to control, ${ }^{*} P<0.01$, relative to animals with nephropathy, $(M \pm m)$; the data are presented as mean \pm SEM 


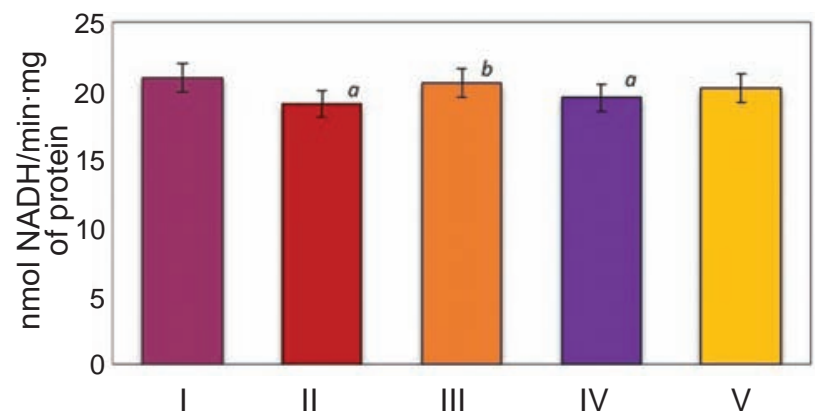

Fig. 1. Activity of succinate dehydrogenase in the mitochondria of the liver: I - control $(n=36)$, $I I$ - nephropathy ( $3^{\text {rd }}$ day, $\left.n=25\right), I I I$ - nephropathy +3 days of glutathione introduction $(n=23), I V-$ nephropathy (7th day, $n=24), V-n e p h r o p a t h y+7$ days of glutathione introduction $(n=23)$; $* P<0.01$, relative to control, \# $P<0.01$, relative to animals with nephropathy, $(M \pm m)$; the data are presented as mean $\pm S E M$

the $7^{\text {th }}$ day of experiment compared to animals of the control group.

The glutathione introduction increased the production of ATP by upregulating the activity of studied enzymes of I, II, V Complexes by $7.8 \%$, $31 \%$ and $20 \%$ on the $3^{\text {rd }}$ experimental day and by $17.7 \%$ and $26.7 \%$ the activity of studied enzymes of II and V Complexes on the $7^{\text {th }}$ day compared to rats with nephropathy accordingly. These results demonstrated an important role of glutathione in the control of ATP production, although we did not detect a change in cytochrome oxidase activity in rats after glutathione introduction.

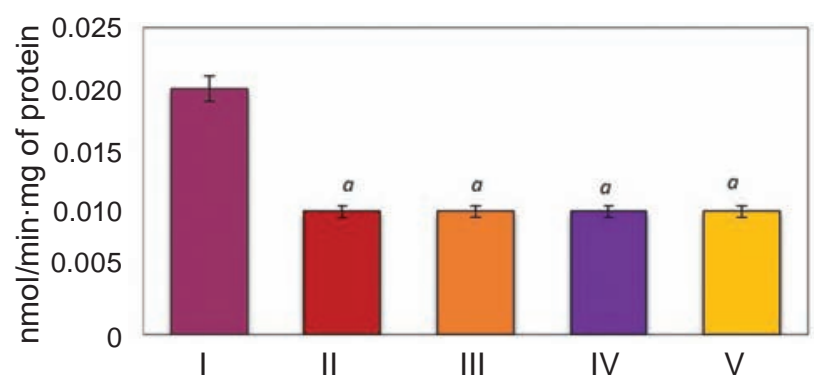

Fig. 3. Activity of $H^{+}$-ATPase in the mitochondria of the liver: I-control $(n=36)$, II - nephropathy (3rd day, $n=25)$, III - nephropathy +3 days of glutathione introduction ( $n=23), I V-n e p h r o p a t h y ~\left(7^{\text {th }}\right.$ day, $n=24), V$-nephropathy +7 days of glutathione introduction $(n=23) ; * P<0.01$, relative to control, ${ }^{\#} P<0.01$, relative to animals with nephropathy, $(M \pm m)$; the data are presented as mean \pm SEM

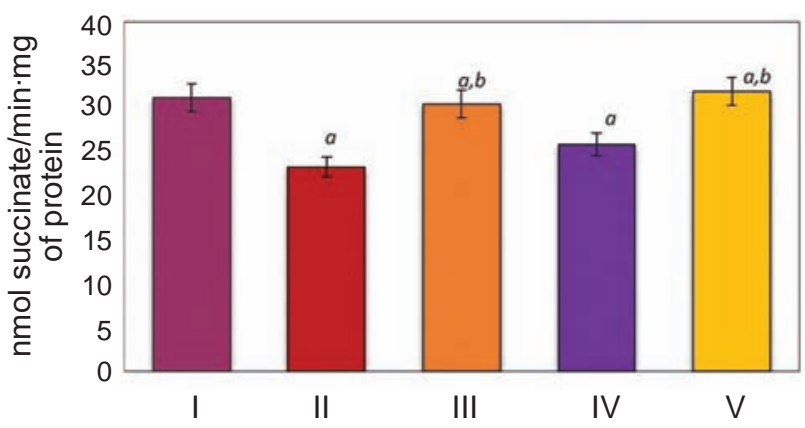

Fig. 2. Activity of cytochrome oxidase in the mitochondria of the liver: I - control $(n=36)$, II - nephropathy (3rd day, $n=25), I I I-$ nephropathy +3 days of glutathione introduction $(n=23), I V-n e-$ phropathy ( $7^{\text {th }}$ day, $\left.n=24\right), V-n e p h r o p a t h y+7$ days of glutathione introduction $(n=23) ; * P<0.01$, relative to control, $(M \pm m)$; the data are presented as mean $\pm S E M$

$\mathrm{SH}$-groups are electron donors in the antioxidant reactions of neutralizing toxic oxidized substrates in the body. We established that in the mitochondrial fraction of the liver of rats with nephropathy the content of free SH-groups (Fig. 4) decreases by $31 \%$ and by $33 \%$ on the $3^{\text {rd }}$ and $7^{\text {th }}$ days of development of pathology accordingly. Maybe these changes indicate the intensification of free radical processes in the mitochondria of the liver.

These findings suggest the progress of disease could have an influence on the mitochondrial bioenergetic state of hepatocytes and development and progression of oxidative stress in the organism.

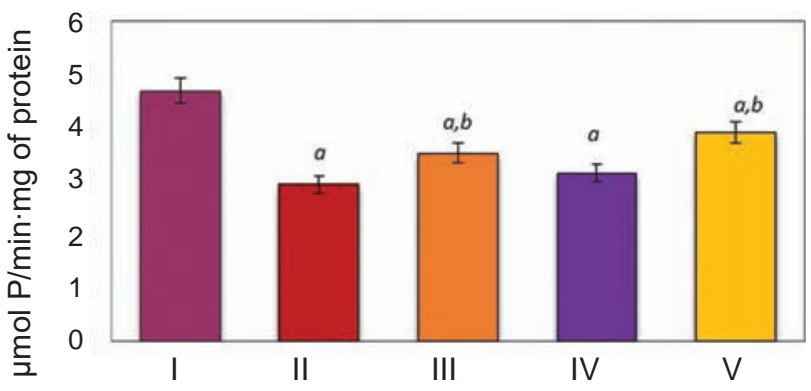

Fig. 4. The content of SH-groups in the mitochondria of the liver: $I$ - control $(n=36), I I-n e p h r o p a-$ thy ( $3^{\text {rd }}$ day, $\left.n=25\right)$, III - nephropathy +3 days of glutathione introduction, $n=23)$, IV - nephropathy ( $7^{\text {th }}$ day, $\left.n=24\right), V-n e p h r o p a t h y+7$ days of glutathione introduction $(n=23) ;{ }^{*} P<0.01$, relative to control, ${ }^{\#} P<0.05$, relative to animals with nephropathy, $(M \pm m)$; the data are presented as mean $\pm S E M$ 
The introduction of glutathione showed that it induced to increase the content of sulfhydryl groups (Fig. 4) at third day (17\%) and seventh day (2\%) compared to groups of animals with nephropathy. We supposed that glutathione plays an important role in protection of the mitochondrial membrane against oxidative damage and the control of ATP production. Changes by glutathione influence may be viewed as a signal for rearrangement of mitochondrial energy generation. In our opinion this is due to the fact, that glutathione has antioxidant properties and decreases reactive oxygen species in mitochondria thereby promoting stabilization of the energy metabolism of mitochondria.

So, the activities of enzymes of energy metabolism in the liver under conditions of nephropathy decreased, thereby exacerbating renal failure. The introduction of glutathione increases activities of enzymes of II, V Complexes of the mitochondrial respiratory chain and is not effective for the activity of cytochrome oxidase in mitochondria isolated from the liver of rats with nephropathy. Maybe this tripeptide might be a new therapy for renal failure. These findings may help widen our understanding of the fundamental metabolism of the organism and the state of mitochondrial energy metabolism in the liver under conditions of development of kidney disease.

Folic acid induced nephropathy exacerbates the oxidative stress and reduced energy-generating function by decreasing the enzyme activities of the mitochondria respiratory chain in the liver.

The result of the work demonstrates a positive effect of 7-days glutathione introduction on enzymatic activities of succinate dehydrogenase and $\mathrm{H}^{+}-$ ATPase. Probably the glutathione promotes upturn of energy metabolism of the liver due to its antioxidant function.

Conflict of interest. Authors have completed the Unified Conflicts of Interest form at http:// ukrbiochemjournal.org/wp-content/uploads/2018/12/ coi_disclosure.pdf and declare no conflict of interest.

\section{ВПЛИВ ГЛУТАТІОНУ \\ НА ЕНЕРГЕТИЧНИЙ ОБМІН У МІТОХОНДРІЯХ ПЕЧІНКИ ЩУРІВ ЗА ЕКСПЕРИМЕНТАЛЬНОЇ НЕФРОПАТІЇ}

\author{
Є. О. Ференчук, I. В. Геруш \\ ВДНЗ України «Буковинський державний \\ медичний університет», Чернівці; \\ e-mail: yelena_f@ukr.net
}

Окисне пошкодження мітохондрій та порушення енергетичного метаболізму призводить до розвитку багатьох патологій та захворювань. У роботі досліджено вплив глутатіону на активність ензимів мітохондріального дихального ланцюга та визначено вміст SH-груп у мітохондріях печінки щурів в умовах нефропатії, спричиненої фолієвою кислотою. Мітохондрії виділяли диференційним центрифугуванням. Визначали активність NADH-дегідрогенази, сукцинатдегідрогенази, цитохромоксидази та $\mathrm{H}^{+}$-АТРази. Показано, що за нефропатії, активність досліджуваних ензимів та вміст SH-груп знижувалась, що може свідчити про інтенсифікацію вільнорадикальних процесів. Введення глутатіону сприяло зростанню вмісту SН-груп і активності ензимів II та V комплексів дихального ланцюга мітохондрій, але не впливало на активність цитохромоксидази в мітохондріях печінки щурів із нефропатією. Одержані результати показали позитивний ефект глутатіону на активність сукцинатдегідрогенази та $\mathrm{H}^{+}$-АТРази.

К л ю чов і слов а: нефропатія, мітохондрії, глутатіон, NADH-дегідрогеназа, сукцинатдегідрогеназа, цитохромоксидаза, $\mathrm{H}^{+}$АТРаза. 


\section{References}

1. Chen LY, Yang B, Zhou L, Ren F, Duan ZP, Ma YJ. Promotion of mitochondrial energy metabolism during hepatocyte apoptosis in a rat model of acute liver failure. Mol Med Rep. 2015; 12(4): 5035-5041.

2. Wadei HM. Hepatorenal syndrome: a critical update. Semin Respir Crit Care Med. 2012; 33(1): 55-69.

3. Nunnari J, Suomalainen A. Mitochondria: in sickness and in health. Cell. 2012; 148(6): 11451159.

4. Kuksal N, Chalker J, Mailloux RJ. Progress in understanding the molecular oxygen paradox function of mitochondrial reactive oxygen species in cell signaling. Biol Chem. 2017; 398(11): 1209-1227.

5. Zhao H, Liu YJ, Liu ZR, Tang DD, Chen XW, Chen YH, Zhou RN, Chen SQ, Niu HX. Role of mitochondrial dysfunction in renal fibrosis promoted by hypochlorite-modified albumin in a remnant kidney model and protective effects of antioxidant peptide SS-31. Eur J Pharmacol. 2017; 804: 57-67.

6. Indo HP, Yen HC, Nakanishi I, Matsumoto K, Tamura M, Nagano Y, Matsui H, Gusev O, Cornette R, Okuda T, Minamiyama Y, Ichikawa $H$, Suenaga S, Oki M, Sato $T$, Ozawa T, Clair DK, Majima HJ. A mitochondrial superoxide theory for oxidative stress diseases and aging. J Clin Biochem Nutr. 2015; 56(1): 1-7.

7. Sies H, Berndt C, Jones DP. Oxidative stress. Annu Rev Biochem. 2017; 86: 715-748.

8. Ghezzi P, Jaquet V, Marcucci F, Schmidt HHHW. The oxidative stress theory of disease: levels of evidence and epistemological aspects. $\mathrm{Br} J$ Pharmacol. 2017; 174(12): 1784-1796.

9. Gupta A, Puri V, Sharma R, Puri S. Folic acid induces acute renal failure (ARF) by enhancing renal prooxidant state. Exp Toxicol Pathol. 2012; 64(3): 225-232.

10. Weinbach EC. A procedure for isolating stable mitochondria from rat liver and kidney. Anal Biochem. 1961; 2(4): 335-343.

11. Sharova IV, Vekshin NL. Rotenone-insensitive $\mathrm{NADH}$ oxydation in mitochondrial suspension occurs by NADH dehydrogenase of respiratory chain fragments. Biofizika. 2004; 49(5): 814-821. (In Russian).

12. Prokhorova MI. Modern methods of biochemical research (lipid and energy metabolism). L.: Leningrad. university. 1982: 272 p. (In Russian).

13. Ostapchenko LI. Biologic membranes: methods and structured structure and functions. K.: Kyiv. un. 2005: 268 p. (In Ukrainian).

14. Gabibov MM. Effect of hyperbaric oxygenation on proton ATPase activity in mitochondria of various rat tissues. Ukr Biokhim Zhurn. 1986; 58(5): 81-83. (In Russian).

15. Lowry OH, Rosebrough NJ, Farr AL, Randall RJ. Protein measurement with the Folin phenol reagent. J Biol Chem. 1951; 193(1): 265-275.

16. Dubinina EE, Burmistrov SO, Khodov DA, Porotov IG. Oxidative modification of human serum proteins. A method of determining it. Vopr Med Khim. 1995; 41(1): 24-26. (In Russian).

17. Lapach SN. Static methods in biomedical research using Exel. K.:MORION, 2000. 320 p. (In Russian). 